\title{
Indigenous Education for Cultural Survival: The Makushi Amerindians of Guyana
}

\author{
Christine Wihak (Thompson Rivers University)
}

\begin{abstract}
The survival of Indigenous cultures is essential to a sustainable future for the planet as a whole. This paper focuses on the educational efforts being made by the Makushi people of inland Guyana to maintain their culture and language in the face of encroaching development. The paper relates the discussion of the Makushi situation and their educational responses to the development challenges in the small states of the Caribbean. Descriptive information is provided concerning the Makushi's efforts, which include initiatives in elementary and secondary education, post-secondary training, and community education. Regardless of the venue, a collective vision of Makushi cultural survival guides their development of educational programs.

Résumé

La survie des cultures indigènes est essentielle à un avenir durable pour l'ensemble de la planète. Ce travail met l'accent sur les efforts éducatifs faits par le peuple Makushi en Guyane intérieure afin de maintenir leur culture ainsi que leur langue face au développement d'empiétement. Le travail se rapporte à la discussion de la situation du peuple Makushi et leurs réponses éducatives aux défis du développement dans les petits états des Caraïbes. Les renseignements descriptifs sont fournis concernant les efforts du peuple Makushi, ce qui inclut des initiatives dans l'enseignement élémentaire, l'enseignement secondaire, la formation postsecondaire, et l'éducation communautaire. Indépendamment du lieu, une vision collective de la survie culturelle du peuple Makushi oriente leur développement des programmes éducatifs.
\end{abstract}

The isolated and remote small states of the Caribbean, such as Guyana, struggle with challenges to social and economic development beyond those facing the rest of the developing world. As described in a recent report prepared by the Food and Agriculture Organization of the United Nations (2005), their natural environments are turbulent and offer limited opportunities for creating a diversified economy. The legacy of colonialism has left them with limited infrastructures, a lack of investment capital and a scarcity of educated individuals. Given these conditions, Louisy (2001) has suggested that in a globalizing world, "the pre-eminent role of Caribbean education" (p. 431) is to prepare individuals to participate in the international context while continuing to ground them in their own cultures and 
context. To this end, much international aid has been focused on capacity building within Caribbean state education systems (Holmes \& Crossley, 2004).

Within the small states context, however, a marginalized group exists: the Amerindians, the Indigenous people of the Caribbean. In the wake of decolonization, a struggle for Indigenous people's rights is taking place across both the developed and the developing worlds. Although Indigenous groups are diverse, their shared ecocentric identities (Wenzel, 1991) and worldview concerning their relationship to the natural world (Friesen \& Friesen, 2005) draws them together on the international stage in opposition to the dominant voice of economic exploitation of natural resources (Rao \& Robinson-Pant, 2006). For Indigenous people, education is a battleground for cultural and linguistic survival, often fought either with inadequate support from or in active opposition to state governments focused on nation-building (Malcolm, 2005; MacPherson, 2003

This paper focuses on the efforts of the Makushi people of inland Guyana to maintain their culture and language in the face of encroaching development. These efforts span a range of educational initiatives, including elementary and secondary education, post-secondary training, and community education. Regardless of the venue or vehicle, a collective vision of Makushi cultural survival guides this educational development.

\section{SPEAKING ABOUT THE MAKUSHI}

Before offering this account of Makushi education, I need first to acknowledge my own position as a "northerner" reflecting on "southern" experience (Afshar, 2005). Mindful of this concern, I sought collaboration in preparing this manuscript with two Guyanese educators who have been and continue to be actively involved with the Makushi community. Continuing difficulties with electronic communication and the press of other commitments prevented their involvement. Nevertheless, as an ecological citizen of the planet (MacPherson, 2005), I felt the Makushi voice ought to be heard.

Indigenous people are keepers of a vital part of our human heritage, a knowledge essential for the survival of our shared home in the face of the developed world's obsession with growth in production and consumption, and the consequent deterioration of our environment (Worldwatch Institute, 2005). If the world honours their wisdom, together we may find a sustainable way to continue to inhabit this globe. [Italics mine] Indigenous languages and cultures with their embedded ecological knowledge, however, are rapidly becoming extinct (McPherson, 2003), already the reported fate of many Caribbean Indigenous groups (M. Forte, 2005). To preserve Indigenous knowledge and support its continued existence in living cultures, we need to acknowledge, celebrate, and learn from Indigenous people's own cultural survival efforts (Malcolm, 2005).

My interpretation of the Makushi situation was influenced by having been conscientized (Freire, 1984) during the many years I worked in post-secondary education in Nunavut (Wihak, 2003, 2005). As the Inuit have increasingly taken education into their own hands, I sought other ways to continue to support Indigenous 
education. My own contact with the Makushi started through a Calgary-based Indigenous organization, Ghost River Rediscovery, which collaborates with their training institute on a youth leadership exchange program (Wihak, Hately, Allicock \& Lickers, 2006). I spent several days accompanying Sydney Allicock, a Makushi leader, who was visiting Canada on speaking tours. Sydney later graciously served as my cultural mentor (Wihak, 2006) during a two week field visit to Guyana, during which I attended public meetings at primary schools in several villages, including the first Makushi Women's Conference, attended a public parent meeting at the regional secondary school, and facilitated a public meeting for youth at the Makushi post-secondary training institute. The following overview of the Makushi educational efforts is based on those experiences, supplemented by a review of relevant government and NGO documents.

\section{THE MAKUSHI CONTEXT}

\section{Demographic, Geographic and Historical Background}

Guyana, on the northern coast of South America, is a developing country, which although rich in natural resources, is currently impoverished (Gafar, 2004). One of nine Amerindian groups in Guyana, the Makushi number approximately 7000 people, a small minority in a country dominated by populations of African and East Indian origin. Living in 14 scattered and isolated villages, they occupy territory in the Rupununi region of southwestern Guyana, an area with two distinct ecosystems: the savannahs of the Guiana Shield and the rainforests of the Amazon Basin (Allicock, 2003). Both of these relatively undisturbed ecosystems are areas of extremely high biodiversity (Funk, 2003). More than mere carbon sinks whose existence allows developed countries to continue profligate use of fossil fuels (J. Forte, 1999), these ecosystems are a miraculous part of our collective planetary heritage.

In 1595, Sir Walter Raleigh became the first European to meet the Makushi when he came to the region looking for gold. European contact remained sporadic for a couple of centuries, with a Dutch trading post established in the early 1700s, followed by Christian missionaries in the mid-1800s. In the late $19^{\text {th }}$ century, Europeans settled in the area as cattle ranchers and to exploit balata (a form of natural latex) and gold in the region. The missionaries and ranchers did impact the Makushi, but large scale industrial development did not penetrate the region. While the Makushi participated in wage employment as ranch hands and servants, balata harvesters, and miners, they also continued a traditional life of shifting cultivation farming, with cassava as the staple crop, supplemented by fishing and hunting (Grutz, 1996).

Following Guyana's independence from Britain in 1966, ranchers in the Rupununi area rebelled against the government in 1969. The rebellion was swiftly and forcibly put down, but the result was an economic collapse in the area. Consequently, most adult Makushi now spend at least some of their lives working as labourers or servants in nearby Brazil (Grutz, 1996; Sizer, 1996) or coastal Guyana. The Rupununi region remained remote and inaccessible into the late 1990s (Allicock, 2003). 


\section{Recent Developments: "The Road" and Iwokrama}

In the mid-90s, two developments occurred with the potential to significantly affect the Makushi's ability to maintain their culture and their language. The first was the development of a road passing through Makushi lands to link Guyana's coastal area with its southern neighbour, Brazil. The second was the creation of Iwokrama, an international rainforest preserve, in their territory.

The road represented a significant threat to the Makushi way of life. It permitted increased access by outsiders to the region, preparing the way for increased development. Mining development was a serious concern, given that the Government of Guyana unilaterally granted a Canadian company exploration rights in lands claimed by the Makushi as traditional territory (Cultural Survival, 1998). The Makushi were also anxious about the effect of road traffic on wildlife, and about truckers bringing drugs and disease to the young people of the area (Allicock, 2001). As expressed in the saying "We must prepare ourselves to use the road - so that the road does not use us" (Allicock, 2003, p. 2), the Makushi saw the need to be active in road management.

In 1989, the President of Guyana offered 360,000 acres of Guyanese rainforest to serve the international community as a "vast laboratory to develop sustainable solutions for the economic, social, and environmental issues related to the management of tropical forests." (CIDA Forestry Advisory Network, 2002, np). In 1996, the Iwokrama International Centre for Rain Forest Conversation and Development was established by an act of the Guyanese Parliament. Although 14 Makushi communities lie in and around the borders of Iwokrama, the decision to create the preserve was taken without consulting them. Ex post-facto consultations did, however, lead to the creation of the North Rupununi Distract Development Board to represent Makushi interests in relation to Iwokrama (Allicock, 2003). The Makushi communities became involved in collaborative management of the preserve, addressing issues such as ownership of the intellectual property represented by traditional knowledge (J. Forte, 1999). In 2002, the President of Guyana agreed to appoint an elected Makushi representative to the Iwokrama Board.

The establishment of Iwokrama attracted worldwide attention and support from international funding bodies, such as the Canadian International Development Agency (CIDA) and its British counterpart the Department for International Development (DFID), as well as NGOs such as the Audubon Society and the Commonwealth Human Ecology Council. With such financial support, the Makushi have undertaken a range of projects in partnership with Iwokrama to support their culture and their language. These projects involved both education and research.

\section{EDUCATIONAL INITIATIVES FOR MAKUSHI CULTURAL SURVIVAL}

The Makushi strategies for cultural survival needed to address two threats. The first was that unless they were equipped to participate in development occurring in their territory, they would become increasingly marginalized and/or assimilated, while environmental destruction associated with development would erode their ability to sustain a traditional lifestyle. The second was that unless new economic 
opportunities were available, their young people would leave to seek jobs in the cities of Brazil and Guyana or in mines and logging camps far away from Makushi territory (Sizer, 1996). The loss of young people would have a devastating effect on the culture. Their educational strategies thus needed to focus both on transmission of Makushi culture, and on equipping the Makushi to participate in shaping a sustainable form of development.

The Makushi face enormous challenges in staying informed about developments affecting their territories and acting collectively to defend their land, their language and their culture. Until recently, there have been few roads and few vehicles. Travel between the small, isolated Makushi communities is generally done on foot or bicycle, or by canoe. The region has no electricity other than a few solarpowered units, no sewage systems, and only rudimentary telecommunications. Potable water continues to be a problem and malaria is endemic to the region. The educational initiatives described below thus represent tremendous accomplishments by a marginalized group.

\section{Curriculum Development Research: Makushi Research Unit}

The Makushi Research Unit (MRU) was established in 1996 by the University of Guyana's Amerindian Research Unit. Professor Janette Forte (now Bulkan) trained Makushi, primarily women with only elementary school education, to conduct research on their traditional knowledge (J. Forte, 1999). In one of the first projects on biodiversity and ethnobotany, the Makushi researchers used solar-powered computers to compile information on the fish, birds, and plant life of the area, as well as sacred stories. They produced a book entitled Mauksipe Komanto Iseru (Sustaining the Makushi Way of Life), as well as several pamphlets in Makushi (Allicock, 2003). The book has been sold on the internet, and proceeds used to support further work.

According to Vanda Radzik, a Guyanese consultant who has worked extensively with the Makushi, this first project "created new role models for Amerindians, both girls and boys, to think about becoming researchers which is an alternative to low-paying jobs or domestic servants. They use their comparative advantage which is their knowledge of their heritage and culture" (quoted in CIDA, 2004, np). Since that original project, the MRU has worked on designing and administering a survey concerning malaria. They are also participating in data collection for research concerning the effects of Iwokrama on the well-being of the Makushi, as measured by physical health status indicators (Wilson \& Bulkan, 2004).

The pride that the Makushi researchers took in their work and the positive reception it has received in Makushi communities was evident at the first Makushi Women's Conference. One of the researchers introduced herself by saying, "I love Makushi more than anything. I love sharing Makushi." During an interactive exercise, when the conference facilitator (Vanda Radzik) asked the participants to indicate their level of satisfaction with job opportunities, members of the MRU stood proudly under the picture of a face showing "Delighted" while the majority of the other Makushi participants stood under a picture indicating "Very, very unhappy". 
Similarly, the MRU women were "quite happy" about the role of cultural values in their lives, in contrast to the other participants, who chose to stand under "very unhappy" or "extremely unhappy". When asked about their level of satisfaction with national and regional governments, the participants moved in a body to stand under faces indicating different levels of unhappiness. But when asked about their feelings about the contribution of the Makushi women's groups, they surged across the room en masse to station themselves under the faces indicating "Happy", "Very Happy" and "Delighted".

\section{Primary Education: Makushi in the Schools}

The development of printed materials has allowed the introduction of formal Makushi language classes in primary schools. Although each Makushi village had a primary school, and Makushi-speaking teachers were being trained through country-wide initiatives (Dalgety, 2000), the curriculum had been entirely based on mainstream culture and language. For example, the one-room schools I visited had signs and posters in English, listing the qualities of a good citizen, or advocating "child friendly education". Other than the constant sound of the savannah winds blowing through the palms, the cries of the parrots, toucans and monkeys above on the forested mountainside, and the people themselves, the schools showed little evidence of being located in Makushi villages.

The Guyana Ministry of Education supported the Makushi language initiative initially as a pilot project (Allicock, 2003). More recently, Makushi language teaching was launched in all Rupununi nursery and primary schools, supported by curriculum materials Let's Read and Write Makushi and My first Grammar Book, as well as workshops for teachers. In addition, a Makushi-EnglishPortuguese dictionary is being developed. The introduction of Makushi instruction is intended not only to preserve the language, but to improve the quality of education in general by providing it to Makushi children in their own language. (LaRose, 2003).

\section{Secondary Education: Annai Secondary School}

Makushi parents were actively involved in planning and construction of the Annai Secondary School, which was established in Makushi territory in October 1999. The residential school serves the 14 Makushi villages, whose youth must leave their villages to obtain secondary education. Before Annai Secondary was established, however, Makushi youth seeking secondary schooling were required to go the residential school in Lethem on the Brazilian border. Even with an improved road, Lethem is a long drive from the Makushi lands, and given the lack of access to transportation in the area, meant that students essentially spent the entire term at the school. Students in residence were not allowed to speak Makushi (S. Allicock, personal communication, Nov. 20, 2001). Attending residential school meant not only being separated from their families for extended periods, but also from their culture, their language and their land.

Annai Secondary School, however, is located within walking distance of the regional transportation hub. The central location allows the students to visit 
their home villages or see relatives from home passing through to the Guyana coast. Although the curriculum remains mainstream and neither the school head nor the teachers are Makushi, the school is embedded in a Makushi environment, and students freely speak Makushi outside of school hours.

Starting with 19 students, Annai Secondary had expanded by 2004 to 234 students, with 36 of these writing Caribbean Examinations Council exams for the first time (Government of Guyana, 2004). At the time I visited the school in 2001, the facilities were still under development. For example, the students asked if I could assist them in acquiring a solar panel to run the lights in the dormitory, so they could work on their homework at night. Since that time, the President of Guyana has visited the region and committed resources for expanding the Industrial Arts Centre and upgrade water and sewage facilities at the school (Government of Guyana, 2004).

The proximity of the school to the Makushi villages means that Makushi parents can play some role, albeit limited, in running the school. At the parents' meeting I attended, the primary topics under discussion were the selection of material for school uniforms and an administrative decision not to retain the services of a teacher the Makushi knew and trusted, although he lacked the formal qualifications needed to teach at the secondary level in Guyana. While effort was made to reach consensus on the uniform question, little discussion or democratic process was evident with regard to the staffing issue, because the school operates under the regulations of the Ministry of Education. For now, Makushi control of Annai Secondary remains elusive.

\section{Nonformal Education: Junior Wildlife Clubs}

The Makushi Junior Wildlife Clubs are a nonformal approach to education, intended to support Makushi youth in acquiring their culture's rich store of ecological knowledge through active exploration. One of the dilemmas facing Indigenous people concerning preservation of their traditional knowledge is that the Europeanderived form of education is unsuitable for its transmission. In traditional life, intergenerational learning took place in naturally occurring situations, with knowledge strongly connected to the natural environment (Rao \& Robinson-Pant, 2006). Through a more culturally-appropriate approach to education, the Junior Wildlife Clubs prepare the Makushi Youth for their roles as stewards of their culture and their territory:

Members meet to study and observe the area's abundant wildlife and to discuss social issues and risks...The Annual Youth Festival...traditional skills competitions, archery, cotton spinning, art poetry and quiz is a big event enjoyed by the young who transfer traditions and cultural pride. (Allicock, 2003, p. 5).

The Junior Wildlife Clubs also offer a form of organized activity for those Makushi youths who either do not qualify to attend Annai Secondary School or choose to remain in their home villages after completing primary school. As of 2004, wildlife clubs existed in all 14 Makushi communities, with a membership of 
around 280. Club members have visited Iwokrama to participate in environmental education programs and receive training in environmental monitoring activities. Representatives of the clubs participate in regional meetings, with training activities designed to develop their leadership, organizational, and public speaking skills (James, 2004).

\section{Bina Hill Institute for Research, Training \& Development}

The North Rupununi Distract Development Board (NRDDB) recognized the need for adult education and post-secondary training to prepare Makushi for their roles in co-management of Iwokrama and for new economic opportunities. To meets these needs, NRDDB created the Bina Hill Institute in 1999 (Allicock, 2003). The Bina Hill facility was constructed with financial support from IUCM Netherlands, while physical labour was provided by the Makushi community and Canadian young people participating in Ghost River Rediscovery's Indigenous Youth Leadership Program. In 2002, the Commonwealth Ecology Council obtained funding to hire administrative and instructional staff to develop and deliver training programs (Bubier \& Bradshaw, 2004).

The goals of Bina Hill Institute are clearly focused on cultural survival, building local capacity for economic development, and environmental management. Between 2002 and 2004, Bina Hill Institute offered training to 1,340 people in areas such as agriculture, business skills and computing and land surveying. Bina Hill Institute is also the venue for meetings and consultations on issues such as changes to the Amerindian Act, other new laws affecting the Makushi, and new development programmes for the region. The Makushi's vision of having a vibrant, Makushicontrolled resource centre is coming to fruition (Bubier \& Bradshaw, 2004).

\section{Radio Paiwomak}

In 2000, the North Rupununi Distract Development Board collaborated with Iwokrama, UNESCO and the Guyana Broadcasting Company to create the first community radio station in the Guyanese hinterlands. Operated by solar energy, the radio offers broadcasts in Makushi and English for approximately four hours/day. All programming is carried out by volunteers, including students from Annai Secondary. Broadcast topics cover matters of local interest such as farming, environmental issues, education and other social issues. Since approximately $85-90 \%$ of Makushi homes have a radio, these broadcasts are a powerful way of building solidarity amongst the remote and scattered communities and strengthening Makushi cultural identity, as well as contributing to language preservation (Government of Guyana, 2005).

\section{FUTURE OF EDUCATION FOR INDIGENOUS CULTURAL SURVIVAL IN THE CARIBBEAN CONTEXT}

Acting from a common vision of cultural survival, the Makushi have undertaken educational efforts that span primary and secondary education, nonformal education for youth, adult education, and community education. In their 
cultural survival efforts, the Makushi are demonstrating cultural creativity. That is, they are not merely trying to preserve traditional culture but rather they are trying to move into the future in a way that allows them to express their cultural values in new contexts.

The Makushi educational initiatives share a spirit with efforts being made by other Indigenous people in the Caribbean (Freeland, 2003) and worldwide (Malcolm, 2005; MacPherson, 2003 Rao \& Robinson-Pant, 2006; Wihak, 2005). The Makushi's location, however, creates a specific context, one characterized by the forces of development in the Caribbean (Louisy, 2001). The status of Guyana as a Caribbean small state has both positive and negative effects.

On the positive side, the lack of development in Guyana's hinterland has allowed the Makushi culture to remain relatively undisturbed compared to many Indigenous cultures in the developed world. Neither the British colonial government nor any of the Guyanese governments in power since the country gained independence undertook massive educational efforts to colonize the minds of Indigenous people, as occurred in Canada and elsewhere (Battiste, 2000). As a consequence, a critical mass of people who speak the language and embody traditional knowledge still exists, making it more likely that the Makushi can resist extinction (MacPherson, 2003). In addition, the Makushi can benefit from the experiences other Indigenous people in the Caribbean (Freeland, 2003) and around the world, working in solidarity with them towards a sustainable future.

The negative side of being a marginalized minority in a Caribbean small state is obviously the lack of funding available to support Indigenous educational efforts. Guyana is a very poor country (Gafar, 2004). While the Guyanese government has made some contribution to the development of Makushi education (Government of Guyana, 2002, 2004), it cannot provide the same level of support that the Inuit, for example, received in developing an Inuktitut curriculum (Government of the Northwest Territories, 1996). The Makushi must therefore continually seek funding from international development agencies, which makes sustained initiatives a problematic issue. In addition, the poverty of Guyana propels the country down a development path. Continuing conflicts over resource exploitation with attendant environmental degradation in Makushi territory is still a distinct possibility.

Threats to Makushi cultural survival are not diminishing. The loss of Makushi culture, and their ability to act as stewards for an ecosystem precious to the whole planet, would be a loss for us all, as is the loss of any Indigenous culture. Canadian international educators working with Caribbean small state governments can support Indigenous efforts in two ways. First, they can advocate for attention to Indigenous issues within mainstream education. Second, those experienced with Indigenous education in Canada have much to offer Indigenous groups in the Caribbean as they struggle for their own cultural survival. By looking for ways to support Indigenous education, we can help stem the continuing extinction of Indigenous cultures and languages. 


\section{References:}

Afshar, F. (2005). Development from within? Southern voices, Northern reflections. Canadian Journal of Development Studies, XXVI, 217-222.

Allicock, S. (2001). Address to Makushi Women's Conference. Surama, Guyana, Nov. 18.

Allicock, S. (2003). Developing partnerships between the North Rupununi District Development Board (NRDDB) and the Iwokrama International Centre Programme for Rain Forest Conservation \& Development. Paper presented at Indigenous Rights in the Commonwealth Caribbean and Americas Regional Expert meeting. Georgetown, Guyana. Retrieved March 1, 2006 from http://www.cpsu.org.uk/downloads/Sydney\%20Allicock.pdf.

Battiste, M. (2000). Maintaining Aboriginal identity, language, and culture in modern society. In M. Battiste (Ed.) Reclaiming indigenous voice and vision (pp. 192-208). Vancouver, BC: UBC Press.

Bubier, N. E. \& Bradshaw, R.H. (2005). The Amerindians of Guyana: Facing up to change while preserving forests and heritage. Retrieved February 24, 2006 from http:// www.chec-hq.org/index.php?id=395

CIDA. (2004). Promoting gender equity in the Caribbean. Retrieved March 9, 2006 from http://www.acdi-cida.gc.ca/cida_ind.nsf/0/ 9A9767B4F7A8FC2885256F170044F 266? OpenDocument

CIDA Forestry Advisory Network. (2002). Support to the IWOKRAMA Rain Forest Program in Guyana Project. Retrieved March 11, 2006 from http://www.rcfa-cfan.org/ english/profile.15.html

Cultural Survival. (1998). Guyana government grants 5.1 million acre mining concession on Indigenous lands. Retrieved March 9, 2006 from Cultural Survival http:// web.archive.org/web/20010630115824/cs.org/publications/featuredarticles/1998/ guyana2.htm.

Dalgety, F. (2000). Networking for success: The Guyanese experience. In Distance Education in Small States, Conference Proceedings (pp.260-263). Vancouver, BC: Commonwealth of Learning.

Food and Agriculture Organization of the United Nations. (2005). Special Ministerial event on food security and sustainable development in small island developing states. Retrieved March 10, 2006 from ftp://ftp.fao.org/docrep/fao/meeting/010/j6222e. pdf.

Forte, J. (1999). Emerging Local and Global Discourses on NTFP use and study: a view from Guyana. Seminar Proceedings, 'NTFP Research in the. Tropenbos Programme: Results and Perspectives', 28 January 1999 (M.A.F. Ros-Tonen, ed.), 33-43. The Tropenbos Foundation, Wageningen, the Netherlands. Retrieved March 9, 2006 from http://www.kacike.org/BulkanTropenbosB.html.

Forte, M. (2005). Extinction: The historical trop of anit-Indigeneity in the Caribbean. Issues in Caribbean Amerindian Studies, VI(4). Retrieved March 14, 2006 from http:// www.centrelink.org/forteatlantic2005.pdf.

Freeland, J. (2003). Intercultural-bilingual education for an Interethnic-plurilingual society: The case of Nicaragua's Caribbean coast. Comparative Education, 39(2), 239-260.

Freire, P. (1984). Pedagogy of the Oppressed. New York: Seabury Press.

Friesen, N. \& Friesen, V. (2005). First Nations in the twenty-first century: Contemporary educational frontiers. Calgary, AB: Detselig.

Funk, V.A. (2003). Biological diversity of the Guinana Shield: An introduction. Retrieved March 13, 2006 from http://www.mnh.si.edu/biodiversity/bdg/BDGProgRpt2003. pdf 
Gafar, J. (2004). The performance of the labour market in Guyana. Canadian Journal of Development Studies, $X X V$, 663-685.

Government of Guyana. (2004). "Education in Rupununi is a success story" says Minister Nokta. GINA Daily Bulletins February 18. Retrieved March 12, 2006 from http:// www.gina.gov.gy/archive/daily/b040218.html\#Education)

Government of Guyana. (2005). Radio PAIWOMAK a success ... plans in train to enhance broadcast. GINA Daily Bulletins, Sept. 12. Retrieved March 11, 2006 from http:// www.gina.gov.gy/archive/daily/b050912.html.

Government of the Northwest Territories. (1996). Inuuqatigiit: The curriculum from an Inuit perspective. Yellowknife, NT: Author.

Government of Guyana. (2002). Guyana's poverty reduction strategy paper (PRSP). Retrieved March 11, 2006 from http://www.povertyreduction.gov.gy/documents/Guyana_PRSP_main_text.pdf.

Grutz, S. (1996). Health and illness in a Makushi community of Guyana. Retrieved March 10, 2006 , from University of Kent - Canterbury website: http://lucy.ukc.ac.uk/Rainforest/PEOPLE/Silkeref 1.html

Holmes, K. \& Crossley, M. (2004). Whose knowledge, whose values? The contribution of local knowledge to education policy processes: a case study of research development initiatives in the small state of Saint Lucia. Compare, 34(2), 197-214.

James, C. (2004). Report on wildlife club and Citizen Science outreach activities. Retrieved March 11, 2006 from http://www.iwokrama.org/library/pdfdownload/Coummunity\%20Outreach\%20 Report\%20to\%20Audubon\%20Feb\%202004.pdf.

LaRose, M. (2003, April 2). Makushi language project launched. Stabroek New. Retrieved March 11, 2006 from http://www.landofsixpeoples.com/gynewsjs.htm

Louisy, P. (2001). Globalisation and comparative education: a Caribbean perspective. Comparative Education, 37(4), 425-439.

Malcolm, G. (2005). Completing the Freiren cycle: Linking Huichol education with global education and international development studies. Canadian Journal of Development Studies, XXVI, 331-344.

MacPherson, S. (2003). TESOL for biolinguistic sustainability: the ecology of English as a lingua mundi. TESL Canada Journal, 20(2), 1-22.

MacPherson, S. (2005). Educating ecological citizens of the blue planet. Canadian Journal of Environmental Education, 10, 141-156.

Rao, N. \& Robinson-Pant, A. (2006). Adult education and indigenous people: Addressing gender in policy and practice. International Journal of Educational Development, 26, 209-223

Sizer, N. (1996). Profit without plunder: Reaping revenue from Guyana's tropical forest without destroying them. Washington, DC: World Resources Institute. Retrieved March 9, 2006 from http://pubs.wri.org/pubs_content_text.cfm?ContentID=1236

Wenzel, G. (1991). Animal right, human rights: Ecology, economy and ideology in the Canadian Arctic. Toronto: U of T Press

Wihak, C. (2005). Culturally relevant management education: Insights from experience in Nunavut. Alberta Journal of Educational Research, 51(4), 328-341.

Wihak, C. (2004). Meaning of being White in Canada. TESL Canada, 21, 110-115.

Wihak, C. (2006). Learning to learn culture: The experience of sojourners in Nunavut. Canadian and International Education,35(1), 46-62.

Wihak, C., Hately, L., Allicock, S. \& Lickers, M. (In press). Eagle and the Condor: Indigenous alliances for youth leadership education. Diaspora, Indigenous \& 
Minority Education.

Wilson, W.M. \& Bulkan, J. (2004, April). Anthropometric indices of nutritional status in Guyanese Makushi Amerindian. Paper presented at the Annual Meetings of the Human Biology Association, Tampa, FL.

Worldwatch Institute. (2005). Vital signs: The trends that are shaping our future. New York: Norton.

Christine Wihak is the Director of PLAR at Thompson Rivers University, Kamloops BC and can be reached at cwihak@tru.ca. 